\title{
Academic Research Council Acute Stent Thrombosis
}

National Cancer Institute

\section{Source}

National Cancer Institute. Academic Research Council Acute Stent Thrombosis. NCI

Thesaurus. Code C123439.

The formation of a clot within a stent less than 24 hours after the stent is placed. (Cutlip DE, Windecker S, Mehran R, et al. Clinical End Points in Coronary Stent Trials: A Case for Standardized Definitions. Circulation. 2007;115:2344-2351) 